\title{
Analisis A-Tokoferol (Vitamin E) pada Minyak Biji Kelor (Moringa Oleifera Lam.) secara Kromatografi Cair Kinerja Tinggi
}

\author{
Puteri Amelia $^{1 *}$, Nurul Fithriyah ${ }^{1}$, Chairul $^{2}$ \\ ${ }^{1}$ Program Studi Farmasi, Fakultas Kedokteran dan Ilmu Kesehatan \\ UIN Syarif Hidaytullah Jakarta \\ ${ }^{2}$ Pusat Penelitian Biologi LIPI Cibinong Bogor \\ *Email : puti_andalusia@yahoo.com
}

\begin{abstract}
Abstrak
Penelitian ini dilakukan untuk menganalisis kandungan vitamin E dalam minyak biji kelor secara Kromatografi Cair Kinerja Tinggi (KCKT).Hasil analisis menunjukkan bahwa variasi metode perolehan minyak (ekstraksi dengan pelarut dan kempa dengan variasi suhu pengeringan sampel) memberikan hasil rendemen minyak dan kandungan $\alpha$-tokoferol yang berbeda-beda. Pada metode ekstraksi yakni maserasi dengan $n$-heksan menghasilkan minyak dengan jumlah $40.01 \%$, sedangkan metode pengepresan mekanis dengan variasi suhu pengeringan sampel $40^{\circ} \mathrm{C}, 80^{\circ} \mathrm{C}$ dan $120^{\circ} \mathrm{C}$ menghasilkan minyak berturut-turut $10 \%$; 7.6\%; dan $6.77 \%$.Masing-masing sampel minyak tersebut menghasilkan kadar $\alpha$-tokoferol berturut-turut $0.235 ; 0.37 ; 0.265$; dan $0.265 \mathrm{mg} / \mathrm{g}$. Untuk mengetahui kualitas minyak tersebut dilakukan analisis kandungan minyak dengan GCMS. Hasil menunjukkan bahwa minyak biji kelor terdiri dari asam lemak tidak jenuh berupa asam oleat dan asam-asam lemak jenuh yang dominan yaitu asam palmitat dan asam stearat.
\end{abstract}

Kata kunci : Biji kelor, minyak, tokoferol, KCKT, kolom C18.

\begin{abstract}
The purpose of the present study was to determine vitamin $\mathrm{E}$ in the seed oil of moringa with High Performance Liquid Chromatography (HPLC). The analysis showed that the variaous method of oil production, produce variations of oil yield and tocopherol content. Maceration extraction method with $n$-hexane produces $40.01 \%$ of oil, while mechanical pressing method with variations of sample drying temperature $40{ }^{\circ} \mathrm{C}, 80{ }^{\circ} \mathrm{C}$ and $120{ }^{\circ} \mathrm{C}$ produce oil $10 \%$; $7.6 \%$; and $6.77 \%$. Each of the oil samples contains $0.235 ; 0.37 ; 0.265$ and $0.265 \mathrm{mg} / \mathrm{g} \alpha$-tocopherol. Determination of oil quality carried by oil contents analysis by GCMS. Result showed that moringa seed oil is composed by unsaturated fatty acids such as oleic acid and dominated by saturated fatty acids such as stearic acid and palmitic acid.
\end{abstract}

Keywords : Moringa seeds, oil, tokoferol, HPLC, C18 coloumn

\section{PENDAHULUAN}

Tanaman kelor atau Moringa oleifera Lam. yang termasuk dalam familia moringaceae merupakan tanaman yang kerap kali ditemukan dan dibudidayakan di berbagai negara seperti India, Filipina, Pakistan, Thailand dan Indonesia (Promkum et al. 2010). Studi sebelumnya telah mendokumentasikan adanya senyawa fenolik, flavonoid, saponin, terpenoid, proantosianidin dan glikosida jantung pada polong/biji dari M.oleifera (Sharma et al. 2012). Biji (polong) kelor mengandung $\pm 38 \%$ minyak yang mengandung vitamin E $(0.01 \%)$ dan beta karoten $(0.014 \%)$ (Bhoomika et al. 2007).

Vitamin E (tokoferol) merupakan salah satu komponen yang terkandung dalam biji buah kelor. Vitamin E merupakan suatu zat antioksidan yang sangat dibutuhkan oleh tubuh manusia karena memiliki peranan penting dalam menjaga keseimbangan sel dari radikal bebas dan menghambat proses oksidasi. Radikal bebas merupakan molekul yang tidak stabil dan sangat berbahaya bagi tubuh karena dapat menyebabkan perubahan pada sel-sel tubuh yang memicu terjadinya proses penuaan dini dan penyakit degeneratif seperti kanker. 
Dengan kemampuannya sebagai zat antioksidan, vitamin $\mathrm{E}$ dapat mengurangi resiko penyebab berbagai macam penyakit, seperti jantung dan diabetes. Selain itu vitamin E juga dapat mengurangi resiko terjadinya pembekuan darah, mencairkan darah beku, mencegah penyumbatan pembuluh darah, menguatkan dinding pembuluh darah kapiler, meningkatkan pembentukan sel-sel darah merah, mengurangi kadar gula darah, memperbaiki kerja insulin serta meningkatkan kekuatan otot dan stamina (Winarsi 2007).

Selain variasi metode perolehan minyak, tingkat kekeringan sampel juga akan menentukan jumlah dan mutu minyak yang dihasilkan. Metode yang akan digunakan dalam perolehan minyak biji kelor ini menurut Ketaren (1986) menggunakan solvent extraction yakni maserasi dengan $n$-heksan dan juga kempa hidrolis dengan variasi suhu pengeringan pada sampel sebelum dikempa. Analisis vitamin E dapat dilakukan dengan beberapa metode seperti Kromatografi Lapis Tipis (KLT), Kromatografi Gas (KG) dan Kromatografi Cair Kinerja Tinggi (KCKT). Pada penelitian ini digunakan metode KCKT karena memiliki kelebihan yaitu: kolom KCKT dapat digunakan berulang kali, resolusi yang didapatkan jauh lebih tinggi daripada metode lain (KLT, spektrofotometer); teknik yang digunakan tidak terlalu tergantung pada kemampuan operator, waktu analisisnya cepat dan cara kerjanya relatif sederhana, selain itu KCKT juga dapat menganalisis senyawa yang tidak mudah menguap dan termolabil (Ekasari 2008).

Dalam penelitian ini dipelajari pengaruh proses perolehan minyak terhadap jumlah rendemen minyak yang dihasilkan dan juga kandungan tokoferol pada masing-masing minyak tersebut. Selain itu, untuk mengetahui kualitas minyak yang dihasilkan dari biji kelor maka akan digunakan alat GCMS untuk mengetahui komponen-komponen asam lemak penyusun trigliseridanya.

\section{METODE PENELITIAN}

\section{Bahan dan Alat}

Bahan uji yang digunakan adalah biji kelor (Moringa oleifera Lam) yang sudah masak dengan spesifikasi kulit warna coklat kehitaman dan isi berwarna putih kotor dengan bau tidak spesifik dan rasa sepah, $n$-heksan, $\mathrm{Na}_{2} \mathrm{SO}_{4}$ anhidrat, standar $\alpha$-Tokoferol ( $\geq 96 \%$ ) grade HPLC, etanol p.a., Tetrahydrofuran (THF) p.a., metanol grade HPLC.

Alat yang digunakan timbangan bahan dan timbangan analitik; grinder; rotary evaporator (Eyela N-1000); oven; seperangkat alat kempa hidrolis (manual); seperangkat instrument HPLC (Perkin Elmer series 200) yang dilengkapi dengan pompa, kolom LiChosper® $\mathrm{C} 18(25 \mathrm{~cm} \times 5 \mu \mathrm{m})$, degasser, detektor spektrofotometer UV/VIS, pemroses data dan interfase; seperangkat instrumen GCMS (Agilent Technologies $6890 \mathrm{~N}$ ); labu Erlenmeyer; corong; botol vial; pipet tetes; beaker gelas; dan alat-alat gelas lainnya.

\section{Prosedur Penelitian}

Penyiapan simplisia dilakukan dengan : Buah yang sudah masak dikupas dan dikeluarkan biji-bijinya. Kemudian biji dikeringkan dengan udara (kering angin). Kemudian kulit biji dikupas/dibuang kulit arinya. Biji yang sudah dikupas dibagi menjadi 4 kelompok untuk memperoleh minyak berdasarkan perlakuan.

\section{Ekstraksi dengan Pelarut}

Sampel dikupas kemudian di giling menggunakan alat grinder.Sampel halus ditimbang sebanyak 130 g sebanyak 3 kali kemudian masing-masing di maserasi dengan $n$-heksan. Ekstrak dikentalkan menggunakan Rotary vacum Evaporator suhu $<40{ }^{0} \mathrm{C}$. Ekstrak kental ditimbang dan dihitung rendemennya.

\section{Pengepresan Mekanis}

Sampel halus ditimbang $130 \mathrm{~g}$ sebanyak 3 kali dan dikeringkan di oven dengan variasi suhu $40{ }^{\circ} \mathrm{C}, 80{ }^{\circ} \mathrm{C}$ dan $120{ }^{\circ} \mathrm{C}$. Pengeringan dilakukan selama 2 jam.Masingmasing sampel di kempa menggunakan alat kempa hidrolis manual dan minyaknya ditampung lalu ditimbang dan dihitung rendemen minyak yang dihasilkan dari masing-masing suhu.Pembuatan larutan induk deret standar $\alpha$-tokoferol. $\alpha$-Tokoferol ditimbang seksama $25 \mathrm{mg}$ lalu diencerkan dengan etanol hingga $50 \mathrm{~mL}(500 \mu \mathrm{g} / \mathrm{mL})$. Diambil $0,5 \mathrm{~mL}$ dan dilarutkan dengan etanol:THF (1:1) hingga $25 \mathrm{~mL}(10 \mu \mathrm{g} / \mathrm{mL})$. Kemudian dibuat deret standar dengan konsentrasi 0,$5 ; 1 ; 2 ; 5$ dan $10 \mu \mathrm{g} / \mathrm{mL}$.

\section{Validasi Metode Analisis} Uji linieritas dan pembuatan kurva kalibrasi 
Seri larutan standar $\alpha$-tokoferol dengan konsentrasi $\quad 0.5-10 \quad \mu \mathrm{g} / \mathrm{mL}$ masing-masing disuntikkan sebanyak $20 \quad \mu \mathrm{L}$ ke dalam instrumen KCKT. Dari data pengukuran dibuat kurva kalibrasi dengan menggunakan persamaan garis regresi linear $(\mathrm{y}=\mathrm{a}+\mathrm{bx})$. Linieritas dari kurva kalibrasi dilihat dengan menghitung koefisien korelasi (r) dari persamaan garis linier.

\section{Uji Batas Deteksi (LOD) dan Batas Kuantifikasi (LOQ)}

$$
\begin{aligned}
& \text { LOQ }=\frac{3,3\left(\frac{s y}{x}\right)}{b} \\
& \text { LOD }=\frac{10\left(\frac{s y}{x}\right)}{b}
\end{aligned}
$$

\section{Uji Perolehan Kembali}

Sampel minyak dari biji kelor ditimbang sebanyak $0.25 \mathrm{~g}$ dan dilarutkan dengan etanol $10 \mathrm{~mL}$, ditambahkan larutan induk dari standar (spike) sebanyak $0.5 \mathrm{~mL}$ lalu dicukupkan volumenya hingga $25 \mathrm{~mL}$ menggunakan etanol:THF (1:1). Dimasukkan ke dalam vial kemudian injeksikan sebanyak $20.0 \mu \mathrm{L}$ ke alat KCKT dan dicatat luas puncaknya. Dan dihitung persen perolehan kembali (recovery) dengan rumus :

$\%$ recovery $=\frac{a-b}{c} \mathrm{x} 100 \%$

$\mathrm{a}=$ kadar terukur sampel yang ditambahkan

spike

$\mathrm{b}=$ kadar rata-rata sampel yang tidak

ditambahkan spike

$\mathrm{c}=$ penambahan spike

\section{Analisis A-Tokoferol pada Minyak Biji Kelor Dengan KCKT}

Sampel minyak dari biji kelor ditimbang sebanyak $0.25 \mathrm{~g}$ dan dilarutkan dengan etanol $10 \mathrm{~mL}$, lalu dicukupkan volumenya hingga $25 \mathrm{~mL}$ menggunakan etanol:THF (1:1). Sampel dimasukkan ke dalam vial kemudian injeksikan sebanyak 20.0 $\mu \mathrm{L}$ ke alat KCKT dengan fase gerak metanol, panjang gelombang $280 \mathrm{~nm}$, dan laju alir 1.0 $\mathrm{mL} / \mathrm{menit}$ lalu dicatat luas puncaknya. Percobaan diulang sebanyak dua kali.

\section{Analisis kandungan minyak biji kelor dengan GCMS}

Sebanyak $0.5 \mathrm{~g}$ minyak dilarutkan dengan Etil asetat $5 \mathrm{~mL}$ lalu disuntikkan ke alat kromatografi gas. Parameter pengujian GCMS mengacu pada penelitian Nassir, et al. (2010).

\section{HASIL DAN PEMBAHASAN}

\section{Perolehan Minyak}

Variasi proses perolehan minyak dilakukan untuk mengetahui jumlah minyak yang dihasilkan dan kadar vitamin $\mathrm{E}$ dari masing-masing minyak yang diperoleh. Metode ektraksi yang dipakai dalam perolehan minyak ini adalah maserasi. Maserasi merupakan ekstraksi sederhana yang dilakukan dengan cara merendam sampel dalam suatu pelarut selama beberapa hari pada temperatur kamar (Sudjadi 1986). Keuntungan dari maserasi adalah cara pengerjaan dan peralatan yang digunakan sederhana dan mudah

\begin{tabular}{|c|c|c|c|c|c|}
\hline \multicolumn{2}{|c|}{ Metode } & \multirow{2}{*}{$\begin{array}{c}\text { Berat sampel } \\
(\mathrm{g})\end{array}$} & \multirow{2}{*}{$\begin{array}{c}\text { Minyak yang } \\
\text { dihasilkan }(\mathrm{g}) \\
52.2\end{array}$} & \multirow{2}{*}{$\begin{array}{c}\text { Persentase (\%) } \\
40.14\end{array}$} & \multirow{2}{*}{ (\%) Rata-rata } \\
\hline & Maserasi & & & & \\
\hline Ekstraksi & dengan $n-$ & 130 & 51.8 & 39.84 & 40.01 \\
\hline & heksan & 130 & 52.1 & 40.07 & \\
\hline \multirow{9}{*}{$\begin{array}{c}\text { Pengepresa } \\
\mathrm{n} \text { mekanis }\end{array}$} & Tempering & 130 & 11.23 & 8.64 & \\
\hline & biji suhu & 130 & 14.77 & 11.36 & 10 \\
\hline & $40^{\circ} \mathrm{C}$ & 130 & 13 & 10 & \\
\hline & Tempering & 130 & 10.75 & 8.27 & \\
\hline & biji suhu & 130 & 8 & 6.15 & 7.6 \\
\hline & $80^{\circ} \mathrm{C}$ & 130 & 10.9 & 8.38 & \\
\hline & Tempering & 130 & 10.29 & 7.92 & \\
\hline & biji suhu & 130 & 8.67 & 6.67 & 6.77 \\
\hline & $120^{\circ} \mathrm{C}$ & 130 & 7.48 & 5.72 & \\
\hline
\end{tabular}

Tabel 1. Data hasil perolehan minyak 
diusahakan (Ketut Ristiasa et al. 2000). Metode selanjutnya adalah pengepresan mekanis dengan berbagai macam suhu pemanasan diantaranya $40{ }^{\circ} \mathrm{C}, 80{ }^{\circ} \mathrm{C}$ dan 120 ${ }^{\circ} \mathrm{C}$. Menurut Ketaren (1986), adanya perlakuan panas pada biji menyebabkan protein yang terdapat di dalam biji terkoagulasi (menggumpal), dan menyebabkanpecahnya emulsi antara minyak dan protein sehingga memudahkan minyak mengalir keluar, sedangkan protein tetap tertinggal di dalam bungkil.

\section{Validasi Kurva Kalibrasi}

Pembuatan kurva kalibrasi $\alpha$-tokoferol dilakukan dengan menghubungkan 5 titik pada berbagai konsentrasi yaitu $0.5 ; 1 ; 2 ; 5$ dan 10 $\mu \mathrm{g} / \mathrm{mL}$. Persamaan garis kurva kalibrasi yang didapat yaitu $\mathrm{y}=17908091+4402.4227 \mathrm{x}$ dengan koefisien korelasi (r) : 0.999991. Koefisien korelasi yang semakin mendekati nilai 1 menyatakan hubungan yang semakin linier antara konsentrasi dengan luas puncak kromatogram yang dihasilkan.

Tabel 2. Data uji linearitas

\begin{tabular}{cc}
\hline Konsentrasi $(\mathrm{C})(\boldsymbol{\mu g} / \mathbf{m L})$ & $\begin{array}{c}\text { Luas puncak }(\mathrm{A}) \\
(\boldsymbol{\mu V} / \mathbf{s})\end{array}$ \\
\hline $\mathbf{0 . 4 8}$ & 2156.71 \\
$\mathbf{0 . 9 6}$ & 4271.09 \\
$\mathbf{1 . 9 3}$ & 8401.82 \\
$\mathbf{4 . 8}$ & 21246.04 \\
$\mathbf{9 . 6 4}$ & 42433.07 \\
\hline
\end{tabular}

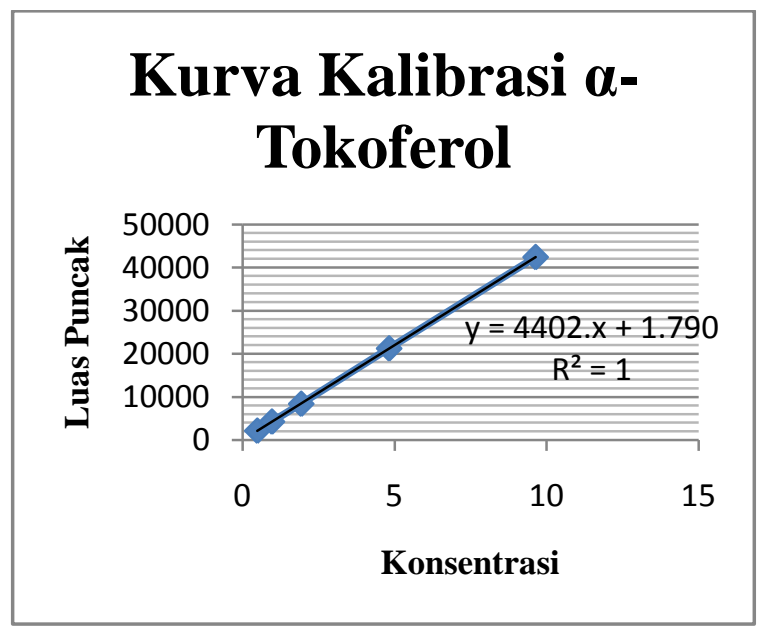

Gambar 1. Kurva kalibrasi standar $\alpha$-tokoferol

\section{Penentuan batas deteksi (LOD) dan batas kuantitasi (LOQ)}

Batas deteksi adalah jumlah terkecil analit dalam sampel yang dapat dideteksi yang masih memberikan respon signifikan dibandingkan dengan blangko. Batas kuantifikasi merupakan parameter dalam analisis renik dan diartikan sebagai kuantitas terkecil analit dalam sampel yang masih dapat memenuhi kriteria cermat dan seksama (Harmita, 2004).Batas deteksi dan batas kuantifikasi $\alpha$-tokoferol yaitu masing-masing sebesar $0.06 \mu \mathrm{g} / \mathrm{mL}$ dan $0.2 \mu \mathrm{g} / \mathrm{mL}$.

Tabel 3. Data penentuan LOD dan LOQ

\begin{tabular}{|c|c|c|c|}
\hline $\begin{array}{l}\text { Konsentrasi } \\
(\mathrm{C})(\mu \mathrm{g} / \mathrm{mL})\end{array}$ & $\begin{array}{c}\text { Luas } \\
\text { puncak } \\
(\mathbf{A}) \\
(\mu \mathrm{V} / \mathrm{s}) \\
(\mathrm{Y})\end{array}$ & $\mathbf{Y i}$ & $(\mathbf{Y}-\mathbf{Y i})^{2}$ \\
\hline 0.48 & 2156.71 & 2114.95 & 1743.59 \\
\hline 0.96 & 4271.09 & 4228.12 & 1846.71 \\
\hline 1.93 & 8401.82 & 8485.26 & 6962.12 \\
\hline 4.8 & 21246.04 & 21133.42 & 12683.31 \\
\hline 9.64 & 42433.07 & 42441.15 & $\begin{array}{c}65.29 \\
\sum= \\
23301.02\end{array}$ \\
\hline \multicolumn{2}{|c|}{ LOD $=0.06$} & \multicolumn{2}{|c|}{$\mathrm{LOQ}=0.2$} \\
\hline
\end{tabular}

\section{Uji Perolehan Kembali}

Kecermatan atau akurasi adalah kedekatan hasil penetapan yang diperoleh dengan hasil sebenarnya (Harmita 2004). Hasil rata-rata uji perolehan kembali pada matriks minyak biji kelor adalah $95.8 \%$. Hasil tersebut sudah masuk kedalam rentang recovery factor untuk analisis vitamin E yakni 90\%-110\% (AOAC SMPR 2011). Maka analisis $\alpha$ tokoferol disini sudah dikatakan akurat. Hasil uji perolehan kembali dapat dilihat pada tabel 4.

\section{Kandungano-tokoferol dalam Sampel Minyak Biji Kelor}

Preparasi sampel untuk minyak biji kelor sebelum di analisis dengan KCKT adalah dengan melarutkan minyak dalam pelarut campuran dari etanol dan THF. Pelarut etanol digunakan untuk memecahkan/memisahkan vitamin $\mathrm{E}$ yang terikat pada membran/ lipoprotein/liposom karena alkohol merupakan medium dimana $\alpha$-tokoferol larut dan bebas mengelusi (Ubaldi 2005). Kadar rata-rata $\alpha$ tokoferol dari sampel minyak hasil ekstraksi 
Tabel 4. Uji perolehan kembali

\begin{tabular}{ccccccc}
\hline No & Bobot sampel $(\mathrm{g})$ & Luas puncak & $\begin{array}{c}\text { Kadar } \\
(\mathrm{mg} / \mathrm{g})\end{array}$ & $\begin{array}{c}\text { Penambahan } \\
\text { spike }(\mu \mathrm{g} / \mathrm{g})\end{array}$ & UPK $(\%)$ & UPK rata-rata (\%) \\
\hline 1 & 0.264 & 52011.17 & 1.1187 & 91.27 & 96.40 & \multirow{2}{*}{95.8} \\
\hline 2 & 0.2637 & 52408.53 & 1.1286 & 91.38 & 95.29 & \\
\hline
\end{tabular}

Tabel 5. Data kadar $\alpha$-tokoferol dari sampel

\begin{tabular}{|c|c|c|c|c|c|c|c|}
\hline \multicolumn{2}{|c|}{ Sampel } & $\begin{array}{l}\text { Waktu } \\
\text { retensi }\end{array}$ & $\begin{array}{c}\text { Luas } \\
\text { puncak }\end{array}$ & $\begin{array}{c}\text { Rata-rata Luas } \\
\text { puncak }\end{array}$ & $\begin{array}{c}\text { Konsentrasi } \\
(\mu \mathrm{g} / \mathrm{mL})\end{array}$ & $\begin{array}{l}\text { Kadar } \\
(\mathrm{mg} / \mathrm{g})\end{array}$ & $\begin{array}{c}\text { Kadar rata-rata } \\
(\mathrm{mg} / \mathrm{g})\end{array}$ \\
\hline \multirow{2}{*}{ A } & 1 & 10.313 & 10150.07 & \multirow{2}{*}{10397.415} & 2.305 & 0.23 & \multirow{2}{*}{0.235} \\
\hline & 2 & 10.347 & 10644.76 & & 2.417 & 0.24 & \\
\hline \multirow{2}{*}{ B } & 1 & 10.41 & 16350.03 & \multirow{2}{*}{16300.365} & 3.71 & 0.37 & \multirow{2}{*}{0.37} \\
\hline & 2 & 10.423 & 16250.7 & & 3.69 & 0.37 & \\
\hline \multirow{2}{*}{$\mathrm{C}$} & 1 & 10.392 & 11680.8 & \multirow{2}{*}{11583.39} & 2.65 & 0.27 & \multirow{2}{*}{0.265} \\
\hline & 2 & 10.419 & 11485.98 & & 2.609 & 0.26 & \\
\hline \multirow{2}{*}{$\mathrm{D}$} & 1 & 10.393 & 11702.13 & \multirow{2}{*}{11473.44} & 2.658 & 0.27 & \multirow{2}{*}{0.265} \\
\hline & 2 & 10.36 & 11244.75 & & 2.55 & 0.26 & \\
\hline
\end{tabular}

Tabel 6 Kandungan senyawa kimia sampel

\begin{tabular}{|c|c|c|c|c|c|}
\hline No & $\begin{array}{c}\text { Nama trivial } \\
\text { senyawa }\end{array}$ & Turunan senyawa & $\begin{array}{l}\text { Waktu } \\
\text { retensi }\end{array}$ & $\begin{array}{l}\text { Quality } \\
\text { (SI) }\end{array}$ & Rumus molekul \\
\hline 1 & $\begin{array}{l}\text { Asam palmitat } \\
\left(\mathrm{C}_{15} \mathrm{H}_{31} \mathrm{COOH}\right)\end{array}$ & $\begin{array}{l}\text { Metilpalmitat/matil n- } \\
\text { heksadekanoat }\end{array}$ & 16.38 & 98 & $\mathrm{C}_{15} \mathrm{H}_{31} \mathrm{COOCH}_{3}$ \\
\hline 2 & $\begin{array}{c}\text { Asam stearat } \\
\left(\mathrm{C}_{17} \mathrm{H}_{35} \mathrm{COOH}\right)\end{array}$ & Metilstearate & 17.96 & 99 & $\mathrm{C}_{17} \mathrm{H}_{35} \mathrm{COOCH}_{3}$ \\
\hline \multirow{3}{*}{3} & \multirow{3}{*}{$\begin{array}{c}\text { Asam oleat } \\
\left(\mathrm{C}_{17} \mathrm{H}_{33} \mathrm{COOH}\right)\end{array}$} & $\begin{array}{c}\text { Trans asamoleat / } \\
\text { trans-9- } \\
\text { asamoktadekanoat / } \\
\text { asamelaidat }\end{array}$ & 18.18 & 99 & $\begin{array}{c}\mathrm{C}_{17} \mathrm{H}_{33} \mathrm{COOH},{ }^{\Delta 9} \\
\text { trans }\end{array}$ \\
\hline & & Metiloleat & 17.81 & 99 & $\mathrm{C}_{17} \mathrm{H}_{33} \mathrm{COOCH}_{3}$ \\
\hline & & Etiloleat & 18.36 & 99 & $\mathrm{C}_{17} \mathrm{H}_{33} \mathrm{COOC}_{2} \mathrm{H}_{5}$ \\
\hline
\end{tabular}

dan dan hasil kempa berbeda presentasinya (Tabel 5).

Hasil uji statistik dengan uji pearson dan juga uji spearman menunjukkan hubungan yang tidak signifikan antara kadar $\alpha$-tokoferol yang dihasilkan dengan proses perolehan minyak maupun dengan perbandingan suhu. Hasil yang tidak signifikan tersebut dinyatakan dengan nilai $\mathrm{p}$ yang dihasilkan adalah 0.333 (signifikan apabila $\mathrm{p}<0.05$ ).

Analisis kandungan minyak biji kelor bertujuan untuk mengetahui kualitas minyak biji kelor. Apabila minyak tersusun dari asamasam lemak yang tidak jenuh maka minyak akan mudah teroksidasi (dengan adanya rantai ganda) menjadi peroksida kemudian menjadi aldehid+keton sehingga minyak tersebut berbau tengik (Winarsi 2007). Hasil yang didapat adalah minyak mengandung asam lemak tidak jenuh berupa asam oleat dengan turunan-turunannya yaitu metil oleat, etil oleat dan bentuk cis-trans dari asam oleat tersebut. Serta asam lemak jenuh yang dominan berupa asam palmitat dan turunannya yaitu metil palmitat, asam stearat dan turunannya yaitu metil stearat.

\section{KESIMPULAN}

Proses perolehan minyak dan pemanasan pada sampel minyak biji kelor tidak mempunyai pengaruh yang signifikan terhadap kadar vitamin E yang dihasilkan dari sampel. 


\section{Daftar Pustaka}

AOAC SMPR. 2011. Determination of vitamin E in Infant and adult/pediatric nutritional formula. Stakeholder panel for infant formula and adult nutritionals Version 7.

Bhoomika R Goyal, Babita B Agrawal, RameshK Goyal, Anita A Metha. 2007. Phytopharmacology of Moringaoleifera Lam. An overview. Natural Product Radiance. 6(4)

Harmita. 2004. Petunjuk pelaksanaan validasi metode dan cara perhitungannya.Majalah Ilmu Kefarmasian 1(3): 117-135.

Ketaren S. 1986. Pengantar Teknologi Minyak dan Lemak Pangan. Jakarta (ID): UI-Press.

Ketut Ritiasa. 2000. Parameter Standar Umum Ekstrak Tumbuhan Obat. Jakarta (ID):
Dirjen BPPOM. Departemen Kesehatan RI: $10-11$.

Nasir, S. Soraya, D.F. Pratiwi, D. 2010. Pemanfaatan Ekstrak Biji Kelor (Moringa oleifera) Untuk Pembuatan Bahan Bakar Nabati , Jurnal Teknik Kimia, No. 3, Vol. 17, Agustus 2010.

Sudjadi. 1983. Penuntun Struktur Senyawa Organik. Bandung (ID): Ghalia Indonesia.

Ubaldi A, Delbono G, Fusari A, Serventi P. 2005. Quick HPLC Method to Determine Vitamin E Concentration in Cow's Milk.Ann. Fac. Medic. Vet. di Parma. XXV :101-110.

Winarsi Herry. 2007. Antioksidan Alami dan Radikal Bebas. Yogyakarta (ID): Kanisus. 